\title{
On the Legal System and Problems of Shareholder's Qualification
}

\author{
Wei Gao \\ School of North China Electric Power University, Beijing 102206, China \\ foggy1009vv@163.com
}

Keywords: Shareholder's qualification; Stock right; Realistic dispute; Legislative status

\begin{abstract}
Under the current situation of legislation, there are many loopholes in the legislation of the confirmation of shareholder qualifications, and the basis for the confirmation of shareholder qualifications is not uniform. These problems lead to the rights of shareholders cannot get effective protection, the contention on the stock right emerge in an endless stream. Taking everything into consideration in our country, a shareholder of a company may be defined as a person who is entitled to the rights and obligations of the company in accordance with the amount of capital invested at the time of the establishment of the company or the shares held by the company after the establishment of the company. Corresponding to this, shareholder qualification is the basis for investors to enjoy and exercise the rights and assume obligations. It is of great significance for investors to obtain investment benefits and assume corresponding responsibilities. In Company Law, to clarify the rights and obligations of shareholders, the legal relationship between the shareholders, the shareholders and the company, and the different organizations of the shareholders and the company, the qualification of shareholders must be confirmed first. Therefore, it is necessary to discuss the acquisition, identification and loss of shareholder qualification. This paper mainly discusses the acquisition, identification and loss of shareholder qualification of limited liability companies, think about the current system and put forward some suggestions combined with the actual dispute cases.
\end{abstract}

\section{The Legal Provisions and Current Situation of the Acquisition, Identification and Loss of Shareholders' Qualification in China}

Acquisition Time of Shareholder Qualification. In accordance with the time when the shareholders join the company, the shareholders are divided into the original shareholders, the subsequent shareholders and the new shareholders in our country. Therefore, the time to obtain shareholder qualification is from the company's establishment to the company's termination of the entire cycle. It can be obtained when the company set up, after the establishment of the company to subscribe for new shares, when the transfer, inheritance, recipient and When the court enforces.

The Commercial Code of Japan provide in the 280th clause that the date on which the new shareholders become shareholders shall begin on the day following the date of payment. Compared with the Japanese Commercial Code, the company law of our country only stipulates the date of incorporation. About the question of when the new shareholders to obtain shareholder status after the establishment of the company, our company law does not make specific provisions.

Condition of Acquisition of Shareholder Qualification. The shareholders' financial contribution to the company is the necessary condition for the shareholders to obtain the qualification of the shareholders. That is to say, the only way to obtain shareholder qualification is the investment to the company. Under the authorized capital system, shareholder qualification is not necessary to obtain the conditions for the payment of shares; but according to the statutory capital system, the premise of obtaining shareholder qualification is the fact that some or all of the shares have been paid to the company. Shareholders should be based on their commitment about investment amount or the amount of subscription of shares to pay the corresponding shares. Only when the shares of the subscribers to fulfill the obligations of payment, and the establishment of the company, can be the subscriber converted into shareholders. If the subscriber fails to perform this obligation, he cannot become a shareholder.

At present, our country is in the transition period from the statutory capital system to the 
authorized capital system, some scholars call it "compromise authorized capital system". There are two ways to obtain the qualification of shareholders, one is the original acquisition, one is subject to the acquisition, the former means direct subscription of the company's shares, which are divided into the establishment of acquisition, capital increase. The establishment of shareholder qualification must meet two requirements, one is the incorporation of the company, and the other is the actual contribution of shareholders. [1]Capital gains are divided into two kinds of limited liability companies and Limited by Share Ltd. In addition to the contribution of investors to invest in the agreement, obtaining the qualification of shareholders of a limited liability company must also have a premise, which is an effective capital increase resolution by the shareholders' meeting of the company in accordance with the procedure. This way of acquisition is also known as derivative acquisition or transfer acquisition, including the gift, transfer, inheritance and acquisition of shareholder qualification for the merger of the company, and no more details here.

The Relevant Provisions of the Current Law on the Qualification of Shareholders. In the Guiding opinions of the supreme people's Court of Beijing Municipality on Several Issues concerning the trial of company disputes (Trial Implementation), there are some regulations about how to confirm the qualification of shareholders of limited liability company. The document stipulates that the qualification of shareholders is the basis for the investors to obtain and exercise the rights of shareholders and the shareholders' obligations. According to the relevant provisions of the Company Law, the confirmation of shareholders' qualification of limited liability companies related to the actual amount of contribution, shareholder equity transfer contract, the company charter, register of shareholders, the investment certificate, business registration and etc. So in the identification of shareholders' qualification, many factors should be comprehensively considered. When specific cases are involved in the examination of facts and evidence, it is necessary to specify the true meaning of the parties to implement civil acts, to identify the criteria for the qualification of shareholders.

But in the current Company Law, there is no clear and explicit stipulation on the qualification of shareholders, but through a number of provisions clearly identify the evidence of shareholder's qualification. For example, in the article 25 of the Company Law, there make some provisions about the matters that shall be clearly recorded in the articles of incorporation of the limited liability company. The name or the apellation of the shareholder, the form of capital contribution, the amount of capital contribution and the time of capital contribution shall be recorded in the articles of association of the company, and the shareholders shall sign and seal the articles of association of the company. The Company Law regulated issues related to the shareholder's financial contribution in the article 28, article 29, article 30, article 32 and article 36. For instance, shareholders should bear the responsibility of investment. Shareholders who funded with money should deposit sufficient amount of capital into the bank account of corresponding company with limited liability. Shareholders who invest in non-monetary assets shall handle the formalities for transfer of financial property rights according to law. After the establishment of the company, the shareholders shall obtain the certificate of capital contribution in accordance with the law. If there is no capital contribution or the existence of false investment, it shall bear the corresponding liability for breach of contract, the shareholders cannot escape their capital contribution. In the Company Law of the article 32, the provisions of the limited liability company must have a register of shareholders, and clearly defined the relevant matters that should be recorded in the register of shareholders, in order to identify the qualification of shareholders. In the Company Law of the article 73 stipulates that after the transfer of equity, the company shall cancel the capital contribution certificate of the original shareholder and issue a capital contribution certificate to the new shareholder, and amend the record of the shareholders' contributions that recorded in company's articles of association and in the register of shareholders. The amendment of the above articles of association of the company shall not be subject to the vote of the board of shareholders.

From the above provisions of the company law, it is clear that the three evidences for the identification of shareholder qualification - basic evidence, the evidence of effectiveness and evidence of confrontation. The evidence of capital contribution as the original evidence of equity 
and the transfer agreement of the evidence obtained by the stock ownership belong to the basic evidence of the confirmation of the shareholder's qualification. The register of shareholders belongs to the evidence of effectiveness. The contents of the relevant industrial and commercial registration as prescribed in the clause 3 of article 32 in the Company Law belong to the counter evidence. The list of shareholders can be used as the evidence of effectiveness because of the nature of equity. In fact, the equity is the relationship between the company and the shareholders, as long as it is recorded in the register of shareholders, should be presumed to be the shareholders of the company, and the shareholders can correspondingly exercise the right including vote, dividend right, etc. [2] However, the company law does not give a positive answer to how to determine the qualification of the shareholders of a limited liability company. And it is just a description of the conditions that should be provided by the shareholders from two aspects: formal and substantial elements. The formal conditions of becoming a shareholder has the following three conditions: the registration of the shareholders of the company, the proof of the shareholder's financial contribution, and the record in the register of shareholders. The substantive elements include two conditions: the signing of the articles of association, and the shareholders are recorded as the shareholders and perform the obligation of capital contribution. Compared to the previous company law, the current company law in the thirty-second article holds a clear attitude towards the effectiveness of the standard of shareholder qualification, clearly defined "the shareholder who was recorded in the list of shareholders can exercise shareholders' rights according to the register of the shareholders, which means that the records in the list of shareholders can exercise the right of shareholders as the basis, which can confirm the qualifications of the shareholders. Among the necessary conditions that shareholders should possess, this is the only necessary condition for a firm to be identified by the law. Other conditions are only in the side for a certain fact behavior was confirmed, but there is no effect affirm the fact behavior, and it cannot play a very good effect in the practice of judicial practice.

Loss of Shareholder'S Qualification. The loss of shareholder's qualification means that the shareholder loses its shareholder's identity due to legal reasons or in a manner prescribed by law.[3] According to the law of our country and the situation of the company in practice, there are several reasons for the loss of shareholder's qualification in the following situations: The termination of a company; the death of the natural person shareholder or the termination of the institutional shareholder; the loss of rights; the transfer of shares; etc. The relevant provisions of the loss of shareholder's qualification is relatively explicitly, and no more details here.

\section{The Shareholder Qualification Dispute in Reality}

In recent years, China has emerged a large number of cases involving the confirmation of shareholder qualification. One of the higher heat and has yet to be resolved, is a well-known landscape cement dispute. That is, on behalf of Zhang Caikui, the old board of directors and the new board of directors arising from the dispute between shareholders and shareholders qualification. Shanshui group is China Shanshui investment limited liability company, which is registered in Hongkong. Shareholders of the company's management of the company's full ownership, including the nine shareholders of the significant. Prior to listing, 3939 shareholders of the shares of employees are required by way of trust by Zhang's trust and Lee trust management, Zhang Caikui and Li Yanmin are trustees, Zhang Caikui and Li Yanmin are trustees. In November 13, 2013, according to the seven named small shareholders and 3939 employees, Zhang Caikui launched two sets of different withdrawal plan. In accordance with the two program, seven small shareholders and 3939 owned by the trust on behalf of management staff will be a piece of Zhang Caikui naturally becomes the sole shareholder. In other words, the original shareholders will be out in 30 years after all, Zhang Caikui will not pay any price on the use of $13.72 \%$ stake in the hands of the company's control of a stake of $100 \%$, the program became the beginning of the dispute between Shanshui cement. In this protracted battle, the group has become a major shareholder of landscape cement and proposed restructuring of the board of directors, but was rejected. May 20, 2016, the 2461 members of the group took over the application of the landscape was Hongkong high court agreed 
that the landscape of the group's stake in the transfer of the third party to take over, Zhang Caikui no longer escrow. Once implemented, Zhang Caikui is likely to lose control of landscape group. May 20, 2016, the 2461 members of the group took over the application of the landscape was Hongkong high court agreed that the landscape of the group's stake in the transfer of the third party to take over, Zhang Caikui no longer escrow. Once implemented, Zhang Caikui is likely to lose control of landscape group.

Because shareholder qualification is the basis of all rights and obligations of shareholders in the company, the competition of the control right contains the dispute about the qualification of shareholders. Zhang Caikui raised about worker shareholder shares and 7 small shareholders after their shares by the Zhang Caikui party, whether they will lose the shareholder qualification and then lost control of the company is a key problem. Whether this plan proposed by Zhang CaiKui in accordance with the relevant provisions on the qualification of shareholders of our country law, control of the hands of Zhang Caikui of Shanshui Cement Group because of the requirements and how the change of his plan, he will therefore become the largest shareholder of Shanshui Cement only, it is what we need to discuss the problem.

In real life, no matter how big or small, there are more and more cases of shareholder qualification disputes, this requires China's laws and regulations to further improve the relevant aspects of the system and legal provisions.

\section{Conclusion: Reflections and Suggestions on Relevant Legal System in China}

According to the research and discussion on the problems concerning the qualification of shareholders in the company law of our country, the author believes that the legal system of shareholder qualification is still not perfect in our country's Company Law. In the company law, there is no specific provision of shareholder qualification, it also leads to the fact that there is no exact law in the case of shareholder qualification confirmation in many practical cases. In addition, after the establishment of the company's registration, when the new shareholders to obtain shareholder status, China's company law has not made clear. However, the content of this aspect is relatively lacking when comparing to the commercial code of Japan and other countries. It is easy to have some ambiguous problems in judicial practice when there does not have definite time and conditions, and will also let the shareholder qualification of the lawsuit in the trial process encountered some difficulties. For example, it is difficult to confirm whether there is a corresponding shareholder qualification, an exact time of the shareholders and so on.

\section{Reference}

[1] X.Y. Hu and J.A. Zhu: Law Science Magazine, Vol. 34 (2013) No.9, p.68-76. (In Chinese)

[2] X.J. Sun: The original theory of Company Law (China Procuratorial Press, China 2011). (In Chinese)

[3] M.L. Yang: Research on the Confirmation of Shareholder's Qualification of Limited Liability Company (MS, JiLin University, China 2013) 